\title{
Mediating spaces acting for the collaboration in the future school
}

\author{
Teräväinen, H., D.Sc.(Tech), Architect, Staffans, A., D.Sc.(Tech), Architect, and \\ Hyvärinen, R., M.Sc. (Geog) \\ Helsinki University of Technology, Helsinki, Finland
}

\begin{abstract}
In this paper we report the performance and preliminary results of studies carried out during the years 2007-2008 in a research project called InnoArch, Places and Spaces for Learning. InnoArch is a part of a large trans-disciplinary InnoSchool consortium (1.1.2007-28.2.2010) aiming to develop a set of research-based good practices, processes, models and designs for the Future School Concept.

InnoArch research has focused partly on "place and mapping", which includes a place-based approach to pedagogical processes. On the other hand the research has concentrated on "space and experience", which includes architectural or spatial analyses of the building and the neighborhood. The spatial experience on each environmental scale is perceived with all senses: sight, hearing, taste, smell, touch and body awareness. Indoor studies are mainly about "creating and experiencing the space", something that has great bearing on architectural thinking when designing the future school.

The non-physical virtual space is seen as a mediator between the physical environment (neighborhood) and the PjBLL (Project Based Learning Lab at Jakomäki School in Helsinki). Places in the physical environment can be located on the commentary map, which will be constructed in the School Forum by teachers and students.

The pupils themselves have an opportunity to personalize the room which is here described as a PJBLL. The room provides possibilities to pursue video observation as well as participative observation and participative design research during architectural workshops. These studies were conducted together with teachers, the pedagogical focus being on TSL processes and the architectural view on physical and virtual spaces. Sustainability is within the focus of both the environmental studies as well as in lifelong and life-wide learning processes. The pedagogical idea based on inquiry-based learning encourages to strengthen pupils' epistemic agency in the local community and to empower them to be active stakeholders in it.
\end{abstract}

Conference theme: Collaborative and interdisciplinary research, education, and design Keywords: learning neighbourhood, physical environment, school design, spatial experiences

\section{INTRODUCTION}

Finland has been successful in the OECD Programme for International Student Assessment PISA (PISA/OECD 2000, 2003, 2007). This programme assesses learning outcomes among 15-year-old students in mathematics, science, reading literacy and problem-solving. Finnish students were rated at the top end in all the lists of the key subjects, and differences between students, schools and regions were comparatively very small.

Good results implicate that there are some qualities in Finnish school system and society that enables quite coherent learning possibilities for pupils. This has inspired academic field to deepen the understanding of the success factors behind these results.
InnoSchool is a multidisciplinary three years (20072009) research project composed of four co-projects. InnoArch is a co-project led by the laboratory of urban planning and design (Department of Architecture, Helsinki University of Technology). Other co-projects are InnoPlay (Centre for Media Pedagogy, University of Lapland), InnoEdu (Faculty on Behavioral Sciences, University of Helsinki) and InnoServe (Simlab, Helsinki University of Technology). TEKES (the Finnish Funding Agency for Technology and Innovation) is the main financier of the project. Additional funds come from several partner companies and cities.

The goal of InnoSchool is to develop the Future School Concept: a set of research based good practices, processes, models and designs, and recommendations for their successful combinations. InnoArch research is concentrating on places and spaces for learning, with the focus on physical environment like school buildings 
and surrounding neighborhoods. In InnoArch the primary goal to deepen the understanding of the interrelationship between a spatial experience and a meaningful learning process (TSL $=$ teaching, studying, learning). The secondary goal is to develop a collaborative, inquiry based planning and design process for the future school. A pilot case for this is the new school of Opinmäki in Espoo that is planned to be built in 2010.

The contribution of InnoArch is to create new environmental design principles, concepts and models, which support inquiry based learning and pupils' epistemic agency by means of architecture and through urban planning and design. InnoArch also aims to strengthen the role of school as a central actor in a learning community and promote shared understanding of our urban space.

Research material in InnoArch is gathered by various methods in collaboration with the existing comprehensive schools; their pupils, teachers and other staff. Project website is http://innoschool.tkk.fi/innoarch

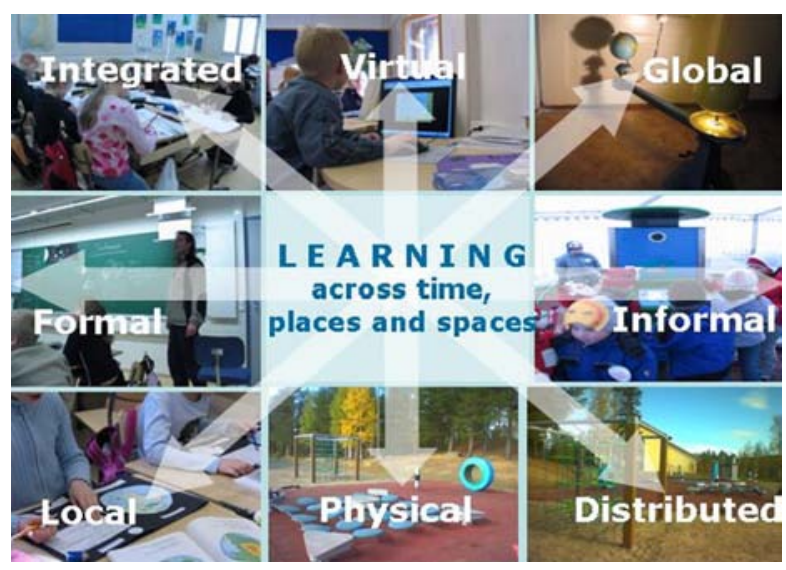

Figure 1. The multi-disciplinary research of InnoSchool.

\section{THE RESEARCH}

\subsection{Research questions}

In this paper we are trying to answer to the following questions we have set earlier ( in the abstract paper) in October 2008. As much as it is possible, regarding the ongoing phase of our research, it will mostly concern the first one:

1) What are the qualities required of a project based learning lab (PjBLL) for it to act as a collaborative and mediating space for both teachers and students?

2) How does the virtual space support linking the PjBLL space and the physical environment locally/globally?

\subsection{Research study - phase 1 (2007)}

In the earlier phase (2007) of the research project at InnoArch we have organized several collaborative planning and design workshops at Arkki (a special
School of Architecture for Children and Youth in Helsinki). The purpose of the workshops was to examine children's visions for a future school and its spaces. Students in two age groups (7-11 and 12-18) were producing ideas of their own in scale models, texts and drawings for the school building and the environment. In that phase our main interest was not only the spaces and places pupils were planning and designing, but also the process: In what ways can the collaborative planning and design process with children act as a tool for active citizenship and cultural learning, and how is this collaborating with the real planning and decision making process? (see appendix 1)

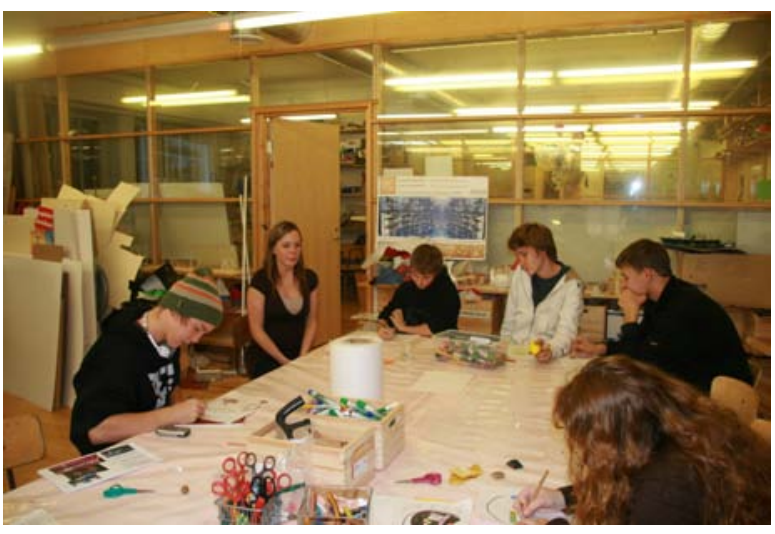

Figure 2. Working around the table at the Arkki School.

\subsection{Research study - phase 2 (2008)}

In autumn 2008 we organized a new and different set of architectural collaborative planning and design workshops. This took place at a normal Finnish comprehensive school and consisted of one workshop of three hours for each group of pupils. The pupils were in two different age levels (10-11 years and 14-15 years) and they came from four different schools in Helsinki.

This time pupils worked in groups and built and designed their own ideas for the future's learning space ("laboratory" or "project based learning lab"). Every group of 4-6 pupils made their own scale model of the room ( 1:6) and personalized it according to their own ideas and desires - after an active discussion and problem solving together. The workshops were actually organized in the very same room that is going to be built into a showcase of future's learning space in spring. Later the pupils are going to work in their projects of different topics in the new space, using the new interior and also new technology with virtual space.

The re-designed space will be later renovated into a project based learning lab (PjBLL) and used further in our multi- and trans-disciplinary research "as a boundary object" (Star \& Griesemer 1989) for the process and network analyses conducted in the other co-project (InnoServe). The space will also be used as a learning space (InnoEdu). 
Table 1. Research Study with children's workshops 2009

\begin{tabular}{cc}
\hline $\begin{array}{c}\text { Chidrens workshops } 2008 \text { making “the space” } \\
\text { for their own place and for the future learning }\end{array}$ \\
\hline $\begin{array}{c}\text { Quantity of children } \\
\text { Quantity of workshops }\end{array}$ & 180 \\
\hline Age of pupils in the workshops & $10-14$ years \\
\hline $\begin{array}{c}\text { Quantity of scale models } \\
\text { The space as one (1 or whole) }\end{array}$ & 28 \\
\hline $\begin{array}{c}\text { The space divided in 2 areas or } \\
\text { rooms }\end{array}$ & 8 \\
\hline $\begin{array}{c}\text { The space divided in 3 or more } \\
\text { rooms }\end{array}$ & 9 \\
\hline $\begin{array}{c}\text { Smaller rooms inside the space } \\
\text { Quantity of models with furniture for } \\
\text { group work }\end{array}$ & 28 \\
\hline $\begin{array}{c}\text { Quantity of models with furniture for } \\
\text { individual work }\end{array}$ & 12 \\
\hline $\begin{array}{c}\text { Flowers, water or some other } \\
\text { elements of nature in the models }\end{array}$ \\
\hline
\end{tabular}

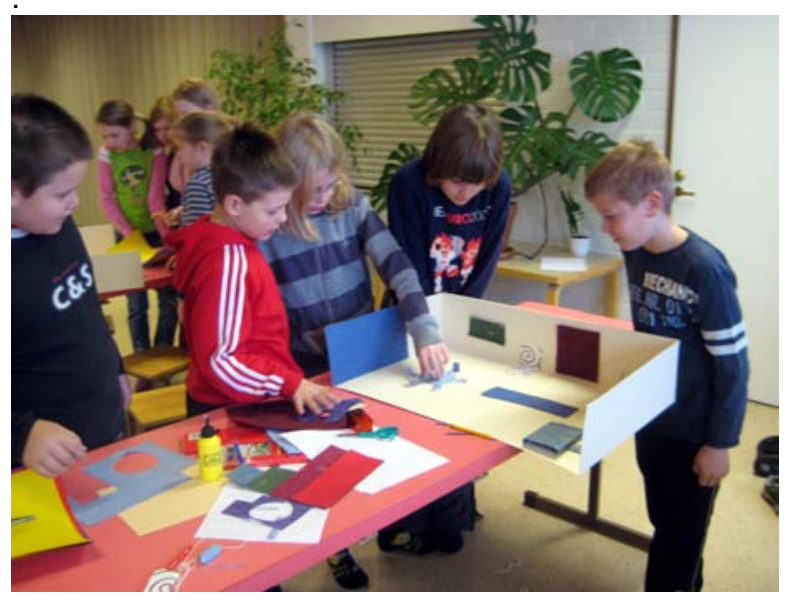

Figure 3. A group of boys (age 10) constructing their " new learning space".

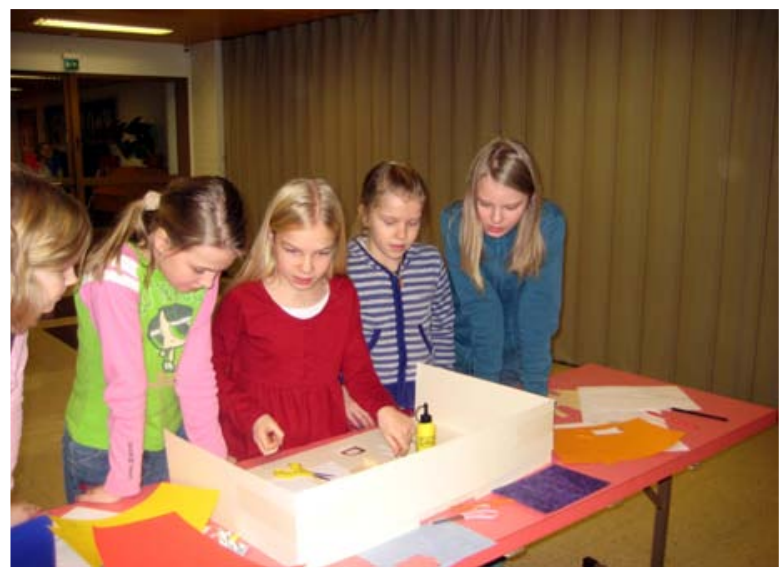

Figure 4. A group of girls (age 10) thinking together materials and furniture in their "learning space for the future".

\subsection{Research method}

All these different workshops at schools (at Arkki, the Architectural School for Children and Youth, and at the four different comprehensive schools) are conducted according to a method called Collaborative Workshop. This could also be described as Collaborative Action Research, which of course is also many other things. Action Research is more of a holistic approach to problem-solving, rather than a single method for collecting and analyzing data.

In these workshops we used two kinds of simultaneously documentation: photographs and videotaping. Discussions and reporting (the researchers, assistants and the pupils) were also used in the workshops. All the material/artifacts the students produced during the meetings have been photographed; drawings also being scanned in digital data. The digital video material and digital pictures have been analyzed both separately (the researcher, the teacher) and together (the students, group of researchers). In the digital video observation we have used Elan multimedia annotator (http://www.latmpi.eu/tools/elan).

The TSL (teaching studying learning) method used here and generally in Finnish architectural and environmental education for children has its ground in "learning by doing" (John Dewey) and also in experiential and reflecting learning as well (see Kolb 1984). Hence it is extremely important to give each student / group of pupils a chance to present his/her/their own work (larger audience via video recordings); while explaining they also learn to clarify their thoughts and to know their rights as members of society, hereby raising children's epistemic agency.

Video taping is also useful in taking notes on how children described their ideas and drawings for the future's learning space. The possibility to document their speech, to listen to their intentions and explanations and to review this material several times in different groups has turned out to be fruitful. This would not have been possible by analyzing only the pictures students created in the workshops.

Further questions regarding video research, such as what do we learn from our investigations while videotaping, editing, and analyzing video - things that we might perhaps never find out without this medium have been uncovered. It appears to bring to the table a new way of understanding not only those we study, but ourselves as documentarists. Repeated viewings of the tapes are not only an affordance but also a challenge. When should one stop reviewing; how much is enough? These problems are perhaps not all unique to video, but in the least they present themselves in a different way. Many researchers talk of how confronting the medium affects and changes the culture one is studying from the moment the camera is turned on (Goldman etc. 2007). The video camera is a representation of the researcher, in some ways more present than a person and often ubiquitous to an absolutely different level. 
One can also ask whether the use of video in research is only an evidentiary tool or also a media form that records stories, convincing viewers and readers of emerging texts and enabling them to understand what happened as the research was taking place. Through an ethnographic lens we can see, as Geertz (1973) has told us, "the importance of being there". We understand, following post-modern ethnographers, that convincing the reader that she was there is not the Truth, but partial truth, a construction of what she experienced and how she interpreted that experience into a textual narrative. (Goldman etc. 2007)

\section{THE THEORETICAL BACKGROUND}

\subsection{Socio-cultural and pedagogical basis}

As a theoretical background InnoArch shares the sociocultural and pedagogical (Vygotsky 1962, 1978) perspective with other co-projects in InnoSchool. We understand the concept "culture" according to the definition of Clifford Geertz (1973, 4-5). He has the idea of culture as "a system of inherited conceptions expressed in symbolic forms by means of which people communicate, perpetuate, and develop their knowledge about and attitudes toward life". The function of culture is to impose meaning on the world and make it understandable for the people living in it.

Lev Vygotsky investigated the development of children and how this was guided by the role of culture and interpersonal communication. Vygotsky observed how higher mental functions developed through social interactions with significant people in a child's life, particularly parents, but also other adults. Through these interactions, a child came to learn the habits of mind of her/his culture, including speech patterns, written language, and other symbolic knowledge through which the child derives meaning and affected a child's construction of her/his knowledge. This key premise of Vygotskian psychology is often referred to as cultural mediation, but the specific knowledge gained by a child through these interactions also represented the shared knowledge of a culture.

Like Piaget (1926, 2002), Vygotsky emphasized the way in which knowledge and understanding are constructed by the learner from their experiences. This is known as constructivist theory. Unlike Piaget, who saw experience as personal, Vygotsky, however, emphasized the social components of experience. His theory underlined the contribution to learning made by others, and is known as a social constructivist view. It has been associated with an apprenticeship approach where the learner learns from someone more experienced or competent. Key ideas in a classroom then become conversation, play and opportunities to follow interests and ideas during the collaborative workshop.

\subsection{Basis in human geography}

We at Innoarch are focusing our research on places and spaces. Our conception of them is here based on the writings of human geographers, like Y. Tuan (1974, 1975, 2001) and E. Relph (1976). According to them, places are not neutral, objective segments of the physical terrestrial reality but sites of concrete human involvement. Places are those 'pieces' of terrestrialspatial reality that have been claimed by human intentions.

The interactions and implications between "space" and "place" are the basic components of the lived world, seen from the perspective of human experience. Interesting way of thinking is Tuan's idea of the place representing the security and the space the freedom. The experiences of the subject in space are most important: how the human being - one who is an animal, able to fantasize and connected to computers experience and understand the world.

\begin{abstract}
Place is a centre of meaning constructed by experience. Place is known not only through the eyes and mind but also through the more passive and direct modes of experience, which resist objectification. To know a place fully means both to understand it in an abstract way and to know it as one person knows another. At a high theoretical level, places are points in a spatial system. At the opposite extreme, they are strong visceral feelings. Places are seldom known at either extreme: the one is too remote from sensory experience to be real, and the other presupposes rootedness in a locality and an emotional commitment to it that are increasingly rare. To most people in the modern world, places lie somewhere in the middle range of experience." (Tuan 1975,51)
\end{abstract}

Tuan is defining "space" and "place" by each other. He also presents how the space is transforming into place (Cresswell 2006,8).

"What begins as undifferentiated space becomes place as we get know it better and endow it with value... The ideas "space" and "place" require each other for definition. From the security and stability of place we are aware of the openness, freedom, and threat of space, and vice a versa. Furthermore, if we think of space as that which allows movement, then place is pause; each pause in movement makes it possible for location to be transformed into place." (Tuan 1977, 6)

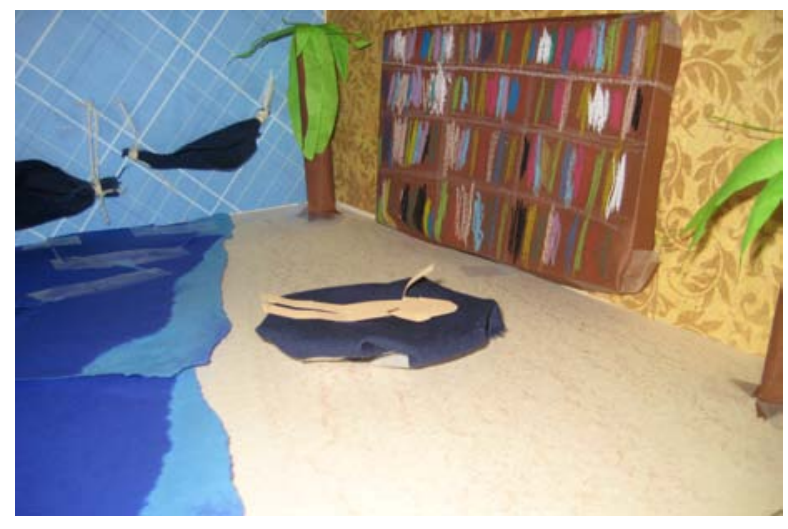

Figure 5. Portugal brought into the class room: hammocks and a book shelve on the sea shore. 


\subsection{Sensory design}

InnoArch research studies are partly concentrating on "place and mapping". This includes place-based approach to pedagogical processes and addresses how they are taking place. And on the other hand we concentrate on "space and experience", which includes architectural or spatial analysis of the building and the neighborhood. The space experience on each environmental scale is perceived with all senses: sight, hearing, taste, smell, touch and body awareness. Indoor studies, like the workshop series at Arkki School are mainly about "creating and experiencing the space", which means architectural thinking when designing the future school. John Dewey's famous "learning by doing" includes also the importance of the experience, both practical and aesthetic. In architectural philosophy, we also like to see in this context the importance and meaning of the spatial experience. (Dewey 1925, 1934)

What if we designed in order to please all of our senses? Suppose for a moment that sound, touch, and odor were treated as equals to sight; and emotion considered as important as cognition. What would our built environment be like if sensory response, sentiment, and memory were critical design factors, the equals of structure and program? Sensory Design (Malnar and Vodvarka 2004) could explore the nature of our responses to spatial constructs - from various sorts of buildings to gardens and outdoor spaces, to constructions of fantasy. This kind of thinking is also involved in the Finnish architectural familiarizing for children; one that could be seen sharply contrast with the Cartesian model of seeing that dominates the architecture today.

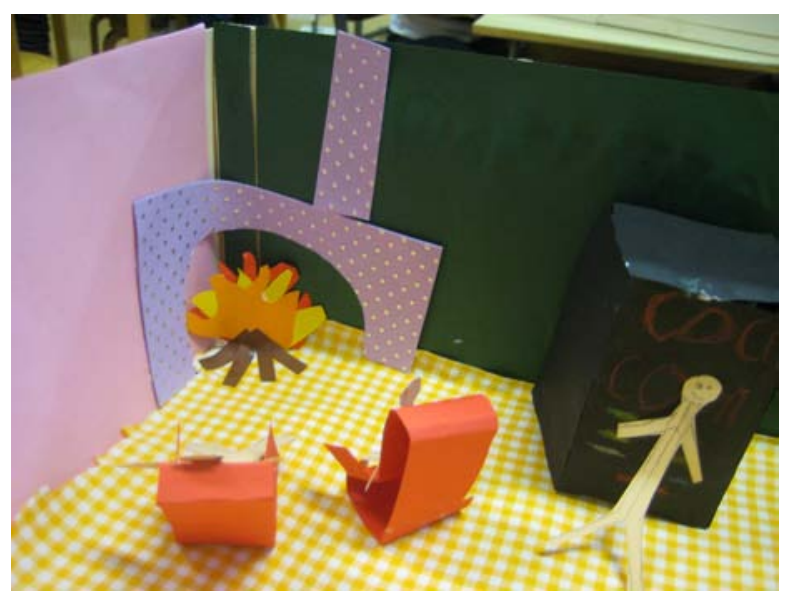

Figure 7. A fireplace brought into the class room.

Cartesian way optical visuality is of course necessary. But it's only half of vision. Haptic visuality, according Laura U. Marks $(2000,2002)$ sees the world as though it were touching it: close, unknowable, appearing to exist on the surface of the image. Haptic images disturb the figure-ground relationship. Optical visuality sees objects as distinct, distant, and identifiable, existing in illusionary three-dimensional space. It maintains a clear, crisp relationship between figure and ground.
Optical visuality is necessary for distance perception: for surveying a landscape, for making fine distinctions between things at a distance. That's how the object of vision is constituted in optical visuality. But by including the haptic vision in design it is possible for architects to understand better the user and his or her spatial experiences and needs. In InnoArch research group was done a master's thesis (two articles) on the area of spatial intensity, concerning haptic visuality (Mäkitalo 2008).

\section{PRELIMINARY RESULTS FROM CHILDREN'S WORKSHOPS}

Here are some preliminary observations of how the learning (TSL) places or the future school would be if the children themselves could be designers: The big centre hall surrounded by smaller spaces came out several times. Many times the rooms were very high and they had balconies, bridges and many levels inside. There were living areas on the roofs, sometimes in open air. It seemed to be important to have access outside directly from every class room. Nature elements like stones, or water elements like fountains, ponds and brooks were placed between the class rooms. Cluster shape appeared and also attempts to share round shape into cornered rooms.

It was marked out that squares or cube-shaped rooms or buildings were issued hardly at all. The students (children) liked to draw round or varying organic shapes. Their imagination seemed to have no limits after they had liberated their thoughts from their contemporary schools. There were no big differences between those children who had been already several years at Arkki School and those who just began this hobby in the autumn.

A student of architecture, Sini Meskanen, who was teaching in the workshops (2007) has afterwards, in her master thesis, presented new typologies of the future school. She developed these on the basis of the data gathered in the workshops, which she analyzed in several forms during the spring 2008. The five typologies were Piazza, Stoa, Series of Atriums, Roof garden and Heart, Bridge and Clusters. The names describe the main findings or ideas in the material produced by the children. (Meskanen, 2008).

In the architectural workshops organized in 2008 at the Jakomäki Comprehensive School there were about 180 children building scale models of the class room. This room was supposed to become a future learning space for the children themselves. After six very hectic collaborative workshops (three hours each) in groups we had 43 models. In 28 models the space (the class room they were working in) was kept as one room, but in 17 models the pupils had divided it in two or more areas or even rooms. Mostly it seemed to be that the children wanted to have different kind of learning furniture for their studies: sack chairs, sofas, hammocks or other swings to accompany the usual desks. Most of the models favored the contemporary Finnish learning system of working in small groups: 28 models featured different kind of tables or other systems for 
collaborative working and mutual social sharing. Five models suggested smaller rooms or little houses inside the class room. Children want to rest or have own privacy when learning individually.
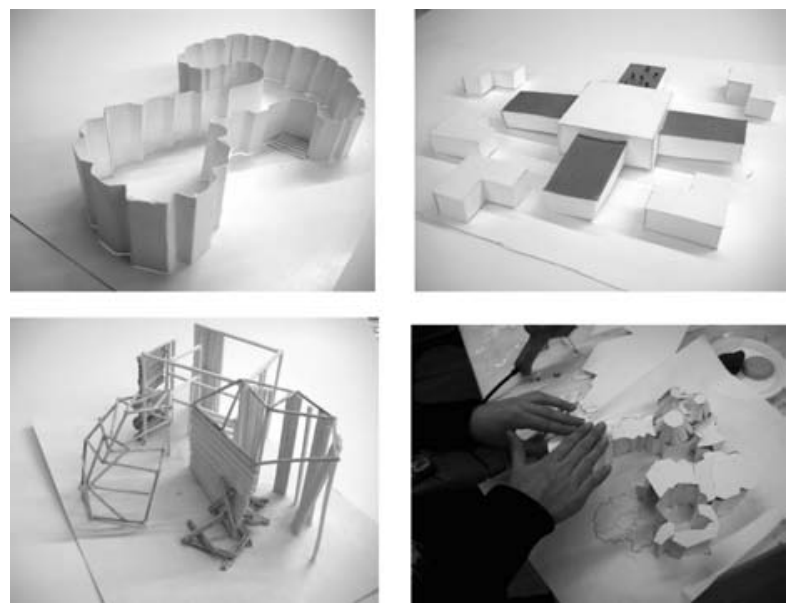

Figure 7._-Models and modelling at Arkki School.

In the workshops one year earlier, in 2007, children "designed" the whole school, but part of their assignment was also to plan learning spaces (rooms) for diverse groups or individuals inside the school house. In these spaces there were more round and soft forms than in the brief modeling workshops in 2008 (naturally because the form of the room as a given= rectangular shaped scale model of the class room they had during this they had during this period ). Also more windows and light, with nature coming in to the room, was featured. But the non-existing limits of the imagination of the children seemed to be the same both at the Arkki School and the normal comprehensive school (without any add-on art education).

In these Jakomäki workshops we have to also remember the social status to be a little bit lower there and the prominent proportion of immigrant families living in the area. Some of the children had yet no shared language or possibly they had not learned to read and write (even if they were already 12-14 years old but having moved to Finland only recently). In Finland we are used to think that every child can read and write after the first year at school (age 7-8; of course some learn earlier). Those boys and girls who were not having language skills could quite nicely use their handwork skills. Foreign countries were brought in to the learning space: Turkey and Portugal were mentioned (perhaps memories from vacations with families) but we saw images also from Russia and Somalia in Africa, from where some of the children were immigrated. In a few models was a foot ball field inside the class room: children can also learn by moving and playing; or some boys had just brought their favorite place in to the space to make it their own.

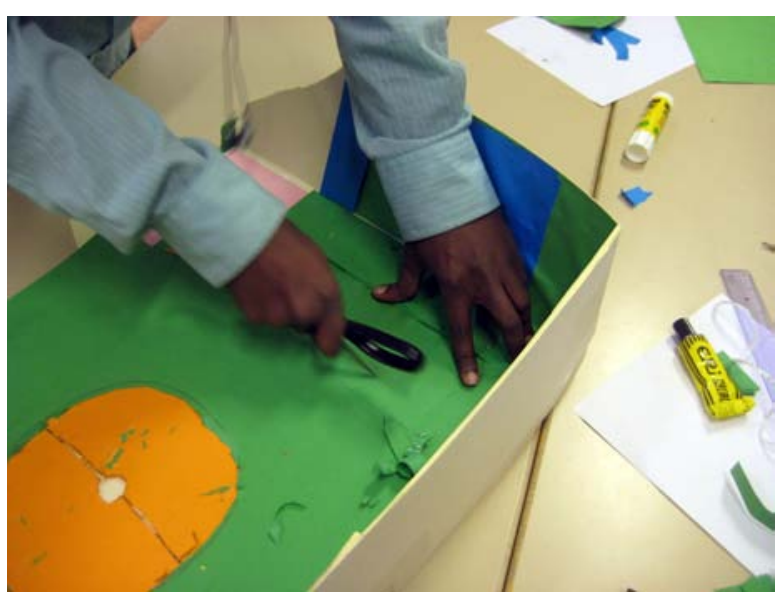

Figure 8. The space (the scale model of the class room) evolving into a foot ball field.

\section{CONCLUSIONS / MEDIATING SPACE}

On the basis of above-presented we have here three preliminary findings of different ways how to see "the mediating space" when planning the future school (learning space and place) with children. The children are active learners at school. The space which is activating them in learning, is considered a mediating space.

1) First we present this process as a personalizing process of the space, "place making" (Tuan 1977 etc.): to children (pupils) have a possibility to bring their own memories, hobbies and ideas into the "space" (the class room) and it will become a place. In making this when "memorizing" their favorite places - the pupils can be advised to use all senses, fearlessly. Without fear, although with the will to find culture within the body, there is no "untamed", uncultured experience; embodied experience is already informed by culture, be it a culture that denies it or one that fosters it (Mäkitalo 2008, 100). And like L.U. Marks is putting it in her text: "Although much of sensory experience is presymbolic, it is still cultivated, that is, learned, at the level of the body" (2002, 145).

2) Vygotsky said that people are also thinking in "a roundabout way", by using mediating tools (Vygotsky 1994, 61; here Säljö 2007, 26). Vygotsky mentioned among the most ancient symbolic mediators "casting lots, tying knots, and counting fingers" (Vygotsky 1978, 127). Beyond these primitive tools lie the vast areas of higher-order symbolic mediators including different signs, symbols, writing, formulae, and graphic organizers. Cognitive development and learning, according to Vygotsky, essentially depend on the child's mastery of symbolic mediators, their appropriation and internalization in the form of inner psychological tools (Kozulin 1998; here Kozulin 2005, 24)

We accept the human mediation (collaboration) to be important, but we try examine the role of the space (class room); could it act as a mediating tool or a mediator. Feuerstein (1990; here Kozulin 2005, 26) has 
presented, in the context of the socio-cultural educational theory, the MLE, Mediated Learning Experience. According to Feuerstein and colleagues $(1980,23)$ the acquisition of MLE does not depend on either the content or the modality of interaction: they used examples of instruction in a preliterate society, and wrote that it is possible for the mediation to take a non-verbal form. The mediator can illustrate his actions to an interested observer with only limited verbal, and even less semantic, interaction occurring. They also argued that the changes occurring as a result of nonverbal mediation transcend both the content and the means by which the content is transmitted.

Following Feuerstein, we argue that the process in which the space became a place in the workshops was a Mediated Learning Experience. In this MLE pupils learned to work together and they had possibility to tell about the places, which are meaningful and important for them, first they could tell it non-verbally (drawings and model workshops 2007, models 2008) and then also in speech (video tapes). In this paper, we present as "Mediating Space" the space which is transforming into a meaningful place in the Mediated Learning Experience; we see in this preliminary phase the Mediating Space to act as a mediating tool in the learning process.

3) We are expecting children's epistemic agency to grow in this MLE, which is a part of the learning process. We see the purpose of learning as not only to preserve knowledge but also to expand and renew it (Engeström 2001).

And of course, the pupils (children or students) learn in this kind of processes, in long and in shorter ones, how to participate and to tell their opinions. As in town planning, where we ask people to collaborate and participate, design process of the school should also allow children (as well as adults like teachers) have the right to come and be part of it.

Participation represents an important strategy in sustainable development. In Finland, citizens' participation in urban planning processes is defined in the Land Use and Building Act implemented in 2000. Since then the planning process has been under intensive development. However, planning is still strongly a game of adults. Environmental psychologists Horelli and Kyttä (Horelli 1997a,b; Kyttä \& Horelli 1997, Kyttä 2003) have made efforts towards recognizing children as citizens, and accepting their right to participate in environmental planning. It is evident that children's competence and their contribution to design are not sufficient to make children legitimate participants or "agents of urban policy".

When we accept childhood as a social category, not merely a transitional phase towards adult life, then we have to ask children and youth their desires and opinions of the environment; and more precisely, as done here, to what kind of learning environment do they long for.

\section{REFERENCES}

Cresswell, T. 2006. Place, a short introduction.

\section{Blackwell Publishing}

Dewey, J. 1925. Experience and Nature.

Dewey, J.1934. Art and Experience.

Engeström, Y. 2001. Expansive learning at work. Towards an activity theoretical conceptualization. Journal of Education and Work, 14, 133-156.

Feuerstein, R., Rand, Y., Hoffman, M. \& Miller, R. 1980. Instrumental Enrichment, Baltimore, MD, University Park Press.

Feuerstein, R. 1990. The Theory of structural cognitive modifiability. In B. Presseien (Ed.) Learning and thinking styles: Classroom applications (pp.68-134). Washington, DC: National Education Association.

Geertz, C. 1983. Local Knowledge: Further Essays in Interpretive Anthropology, Basic Books 2000 pb.

Geertz, C. 1973. The Interpretation of Cultures, Basic Books 2000 paperback

Goldman, R., Pea, R., Barron, B. \& Derry S.J.(ed.) 2007. Video Research in the Learning Sciences. Lawrence Erlbaum associates, Publishers. Mahwah, New Jersey

Horelli, L. 1997a. Challenges of children's participation in urban planning, pp. 131-138 in Camstra, R.(ed.), Growing Up in a Changing Urban Landscape. Assen: Van Gorcum. 64 s. ISBN 978-0-11-271153-7.

Horelli, L. 1997b. 'A methodological approach to children's participation in urban planning', Housing, Theory and Society, 14:3, $105-115$

Kolb, D. A. 1984. Experiential Learning. Experience as Source of Learning and Development. Engle wood Cliffs, NJ: Prentice Hall.

Kozulin, A. 2005. Psychological Tools and Mediated Learning. In A.Kozulin (ed.): Vygotsky's Educational Theory in Cultural Context. Cambridge University Press

Kyttä, M. 2003. Children in outdoor contexts, Affordances and Independent Mobility in the Assessment of Environmental Child Friendliness. Dissertation for the degree of Doctor of Philosophy, Helsinki University of Tehncology, Centre for Urban and Regional Studies A28. Espoo.

Kyttä, M. and L. Horelli 1997 "Children's participation in planning and neighbourhoodimprovement - a Methodological challenge". Paper presented at the Urban Childhood-conference in Trondheim, Norway, 912 June.

Malnar,J. M., and Vodvarka, F. 2004. Sensory Design. Minneapolis: University of Minnesota Press. 
Marks, L. U. 2002. Touch - Sensuous Theory and Multisensory Media. Minneapolis: University of Minnesota Press.

Marks, L. U. 2000. The Skin of the Film - Intercultural Cinema, Embodiment, and the Senses. Durham: Duke University Press.

Meskanen, S. 2008. "The Future School. New School Typologies" Master Thesis in Architecture. Helsinki University of Technology.

Mäkitalo, A. 2008. "Spatial Intensity: What Constitutes Experiential Space and How We Perceive It ." Master Thesis in Architecture. Helsinki University of Technology.

PISA 2006. Science Competencies for Tomorrow's World. Volume 1: Analysis. OECD Reports 2007.

Piaget, Jean. 1926; 2006. The Language and Thought of the Child. Routledge

Relph, E. 1976. Place and placelessness. Great Britain.

Star, S., L. \& Griesemer, J. R. (1989). Institutional Ecology, 'Translations' and Boundary Objects:
Amateurs and Professionals in Berkeley's Museum of Vertebrate Zoology, 1907-39. Social Studies of Science,Vol. 19, No. 3, pp. 387-420.

Säljö, R. 2007. Lärande \& kulturella redskap. Om lärprocesser och det kollektiva minnet. Scandbook, Falun.

Tuan, Y. 1974. Topofilia. A study of environmental perceptions, attitudes and values. Prentice-hall, New Jersey, Englewood Cliffs

Tuan, Y. 1975.."Place: an experiential perspective." The Geographical Review 65, 2, pp. 151-16

Tuan, Y. 2001. Space and Place. The perspective of Experience.

Vygotsky, L.S. 1962. Thought and Language. Cambridge, MA: MIT Press.

Vygotsky, L.S. 1978. Mind andSociety. Cambridge, MA: Harvard University Press. 


\begin{tabular}{|c|c|c|c|}
\hline Meetings & Date/ Dates & Topics & Preliminary observations \\
\hline \multirow[t]{2}{*}{ 1. workshop } & \multirow[t]{2}{*}{26.9 .2007} & $\begin{array}{l}\text { 1. What should be } \\
\text { changed at school? }\end{array}$ & $\begin{array}{l}\text { More fun, new technology and beauty. More day } \\
\text { light. More windows. }\end{array}$ \\
\hline & & 2. A nice place & A café, a round places, sofas and soft chairs \\
\hline 2. workshop & 2.10. \& 3.10 & $\begin{array}{l}\text { Future space (own) to } \\
\text { work and learn (1) }\end{array}$ & $\begin{array}{l}\text { PCs, smart boards, screens. Round shapes, } \\
\text { transparent walls and cupolas, roof like the sky, } \\
\text { green nature and bright colours, } \\
\text { futuristic shapes in the furniture, ball-shaped } \\
\text { chairs, sofas; separate moveable spaces, learning } \\
\text { modules also outside. }\end{array}$ \\
\hline 3. workshop & 23.10. \& 24.10. & $\begin{array}{l}\text { Common places at } \\
\text { Future School }\end{array}$ & $\begin{array}{l}\text { Halls, corridors, lunch rooms, great (festival) halls, } \\
\text { jumping halls. Open doors and walls, glass walls, } \\
\text { windows. }\end{array}$ \\
\hline 4. workshop & 30.10. \& 31.10. & $\begin{array}{l}\text { Meeting points and } \\
\text { routes }\end{array}$ & $\begin{array}{l}\text { Entrance and centre halls and all the other big halls } \\
\text { like for physical education and feasts. Currents of } \\
\text { people. }\end{array}$ \\
\hline 5.workshop & $6.11 . \& 7.11$ & $\begin{array}{l}\text { The outside } \\
\text { environment of the } \\
\text { school }\end{array}$ & $\begin{array}{l}\text { Students were longing after nature: and works of } \\
\text { art. Places to stay were cosy and peaceful, } \\
\text { bordered by green belts. Many seats. Water in } \\
\text { many different elements: ponds, rivers with } \\
\text { bridges, falling waters. Plants to see and eat. } \\
\text { Different surfaces, different materials, labyrinths, } \\
\text { various levels: staircases, ramps etc. Roofs as } \\
\text { playgrounds and gardens. }\end{array}$ \\
\hline 6. workshop & 13.11. \& 14.11. & $\begin{array}{l}\text { The future curriculum } \\
\text { and the new subjects. } \\
\text { Specific spaces. }\end{array}$ & $\begin{array}{l}\text { Future subjects: physics-astronomy, design (art, } \\
\text { craft and mathematics), technology, architecture, } \\
\text { medicine and so called "multi creativity". }\end{array}$ \\
\hline 7. workshop & $20.11 . \& 21.11$ & $\begin{array}{l}\text { Future Spaces to study } \\
\text { and learn (groups) (2) }\end{array}$ & $\begin{array}{l}\text { Organic shapes. Cell shape came out and also } \\
\text { attempts to share round shape into cornered }\end{array}$ \\
\hline 8. workshop & $27.11 . \& 28.11$ & $\begin{array}{l}\text { Future Spaces to study } \\
\text { and learn (clusters) (3) }\end{array}$ & $\begin{array}{l}\text { rooms. } \\
\text { The big centre hall surrounded by smaller spaces } \\
\text { (class rooms) came out several times. Rooms were } \\
\text { very high with balconies, bridges and many levels } \\
\text { inside. On the roofs open air living areas. Access } \\
\text { outside directly from every class room. Nature } \\
\text { elements like stones or water elements like } \\
\text { fountains, ponds and brooks, were placed between } \\
\text { the class rooms. }\end{array}$ \\
\hline 9.workshop & 4.12. & Shaping and modelling & Organic, morphological, sculptural shapes. Stairs \\
\hline 10. workshop & 11.12. \& 12.12, & $\begin{array}{l}\text { the school house. } \\
\text { Photographing the } \\
\text { models. }\end{array}$ & $\begin{array}{l}\text { like Guggenheim's, rhythm like Reima Pietila's. A } \\
\text { lot of greenery and water. Pilotism. Bridges } \\
\text { between houses on pillars. Multi-shaped buildings. } \\
\text { Houses resembling rocky stones. Many interesting } \\
\text { roof windows. Steps with lawn. Shelters and sun } \\
\text { awnings. Round buildings divided in sectors etc. }\end{array}$ \\
\hline $\begin{array}{l}\text { Seminar at } \\
\text { Arkki School }\end{array}$ & 19.12. & $\begin{array}{l}\text { Discussion about all } \\
\text { topics and creations } \\
\text { together with parents }\end{array}$ & $\begin{array}{l}\text { A huge amount of fantastic drawings and models. } \\
\text { The overall picture was cleared up to, when } \\
\text { everything was repeated and analysed together. } \\
\text { The students (pupils) had again opportunity to } \\
\text { explain their solutions to the audience. }\end{array}$ \\
\hline
\end{tabular}

Appendix 1. The workshops at Arkki School 2007. 